\title{
Doživljanje prehoda iz zaposlitve strokovnega delavca $v$ vzgojno-izobraževalni praksi v zaposlitev visokošolskega učitelja v kontekstu procesov postmoderne družbe
}

\author{
Ana Bogdan Zupančič \\ Univerza na Primorskem \\ ana.bogdan.zupancic@pef.upr.si
}

V prispevku se osredotočimo na problematiko prehoda med zaposlitvami kot stalnice $v$ življenjskih potekih sodobne postmoderne družbe. Posebno pozornost namenimo prehodu iz zaposlitve strokovnega delavca v vzgojnoizobraževalni praksi v zaposlitev visokošolskega učitelja, kjer gre poleg pričakovanih težav prehajanja zaradi individualnih značilnosti posameznika pričakovati še tiste, ki so posledica individualizacije (stresa). S kvalitativno raziskavo, v katero smo vključili osem posameznikov (moška slovnična oblika se uporablja za vse udeležence raziskave ne glede na spolno identiteto, tudi v prid zagotavljanja anonimnosti) z izkušnjo izpostavljenega prehoda, smo raziskovali doživljanje slednjega, v povezavi z nekaterimi procesi sodobne postmoderne družbe. Analiza je pokazala na prisotnost posledic individualizacije (individualizacije težav, diktata vseživljenjskega učenja), ki jih udeleženci sprejemajo kot »naraven«, samoumeven del prehodov, opozorila na pomen zadostne količine identitetnega kapitala za uspešno adaptacijo in potrdila odsotnost kolektivne podpore novincem $v$ akademskih zaposlitvah.

Ključne besede: prehod med zaposlitvama, individualizacija, identitetni kapital, visokošolski učitelj, postmoderna družba

\section{Uvod}

Prehodi med zaposlitvami so v »svetu dela« postali stalnica, zato je tak svet zahtevnejši (tudi stresnejši, op. a.) in kot tak od posameznikov pričakuje samozaupanje ter nenehno delo na sebi (Drobnič 2020). To lahko vidimo tudi v kontekstu, ki ga izpostavita Pavličeva in Šadlova (2019), ko gre za pretirano ukvarjanje s samim seboj kot posledico procesa individualizacije, ${ }^{1}$ ki posame-

\footnotetext{
${ }^{1} \mathrm{Na}$ tem mestu moramo opozoriti na pomembno razliko med uveljavljenim pedagoškim konceptom individualizacije, ki se udejanja kot sodobna pedagoška praksa in poudarja pomembnost upoštevanja individualnih potreb, značilnosti, interesov ipd. posameznikov, vključenih v
} 
znike odvrača od povezovanja in posledično kolektivne pomoči in podpore. $\checkmark$ takih primerih je torej prehod definiran kot psihosocialen proces soočanja s spremembo zaposlitve na ravni posameznika, podvržen učinkom individualizacije (kot o njej Pavličeva in Šadlova (2019)), med katero spada tudi individualizacija težav posameznikov (Rener 2007).

Med individualizirane ${ }^{2}$ težave štejemo negotovost, nestalnost in nesamoumevnost zaposlitve za nedoločen čas, ki jih večina avtorjev (Drobnič 2020; Pavlič in Šadl 2019; Ule 2017 ipd.) izpostavlja kot stalne dejavnike tveganja in izvora stresa ${ }^{3}$ v postmoderni družbi. Posledica tega so pritiski in stresi, tako Uletova (2017), med katerimi prevladujejo taki, ki so posledica potrebe po nenehnih izbirah in občutka negotovosti, tesnob v zvezi s pravilnostjo odločitev in izbir. Z njimi naj bi se posameznik na področju zaposlovanja sprijaznil tako, da bi se naučil sam obvladati "problematiko prehodov med zaposlitvami, izgrajevati svoj karierni razvoj, ki postaja ključni del njegove samopodobe« (Drobnič 2020, 169).

Če se osredotočimo na specifičen prehod iz zaposlitve strokovnega delavca v vzgojno-izobraževalni praksi v zaposlitev visokošolskega učitelja (v nadaljevanju prehod), ${ }^{4}$ je smotrno vprašanje glede razlik med stopnjami ${ }^{5}$ in-

vzgojno-izobraževalne procese, in med procesom individualizacije, kot jo definiramo v pričujočem prispevku. $V$ slednjem tako izhajamo iz sociološke opredelitve individualizacije, ki pomeni, da vso odgovornost za nastale situacije, težave, za doživljanje in reševanje le-teh (tudi takih, povezanih s stresom na delovnem mestu) ter za uspešnost/neuspešnost soočanja s temi družbenimi situacijami in težavami pripiše zgolj individuu. $S$ tem so popolnoma spregledani pomembni družbeni vidiki - kontekst situacij, družbena (strukturna in sistemska) vpetost in posledično kolektivna odgovornost -, ki naj bi bili izhodišče za kolektivne in politične akcije (Pavlič in Šadl 2019; Rener 2007).

${ }^{2}$ Kot individualizirane težave razumemo tiste, ki so poledica procesa individualizacije.

${ }^{3}$ Lahko bi torej rekli, da kaže nestalnost zaposlitev oz. prehajanje med zaposlitvami umestiti med enega od sestavnih elementov stresa na delovnem mestu, ki bi ga opirajoč se na individualistična izhodišča lahko definirali kot zgolj individualno doživetje v situacijah, ko je posameznik soočen z (ogrožajočimi) spremembami v okolju, previsokimi zahtevami, za katere ta posameznik oceni, da jih ne zmore obvladati (oz. nadzirati, nanje vplivati, op. a.) (Lazarus 1976 v Pavlič in Šadl 2019). Proces adaptacije na »ogrožajoče« spremembe, ki jih prehodi prinašajo, je v obdobju individualizacije življenjskih potekov, ko se družbene zahteve, odgovornosti, urejanja preložena na posameznika (Ule 2017), zgolj odgovornost slednjega. Po drugi strani pa Pavličeva in Šadlova (2019) opozarjata, da je t. i. stres na delovnem mestu, kot eden ključnih rizičnih dejavnikov za psihofizično zdravje zaposlenih, tudi družbeni problem in odgovornost.

${ }^{4} \mathrm{~V}$ prispevku se pojavlja tudi omemba prehoda s strokovne oz. praktične ravni na akademsko raven, ki je v tem primeru »sinonim« za prav ta prehod, uvedemo pa jo zaradi lažje berljivosti teksta.

${ }^{5} \mathrm{~S}$ pojmom stopnja želimo ponazoriti moč procesa individualizacije na kontinuumu od nizke preko srednje do visoke. 
dividualizacije težav (ter posledično tudi stresa na delovnem mestu, op. a.) znotraj delovnih organizaciji na prvi oz. drugi ravni.

Na podlagi družbenih kritik, ki opozarjajo na privatizacijo in komercializacijo javnega šolstva z visokošolskim sistemom na čelu (Burcar 2012; Laval 2005; Zaviršek 2018), bi kazalo posebej izpostaviti, da neoliberalna država univerzam vsiljuje korporativno-poslovni model delovanja, ki drastično vpliva tudi na kvaliteto poučevanja in poglobljeno raziskovalno delo (Burcar 2012). Med drugim prihaja do prehoda »od horizontalnega kolegialnega in učiteljskega upravljanja [...] k hierarhični menedžersko-administrativni strukturi, ki jo zaznamuje delegiranje nalog in vsebin tako pedagoškega kot raziskovalnega dela $v$ skladu $z$ interesi zunanjih določevalcev politik izobraževanja in raziskovanja« (Lustig 2005 v Burcar 2012, 246). Kar pomeni, da so visokošolski učitelji pod nenehnimi pritiski povečanja učinkovitosti in produktivnosti, ki zmanjšujejo obseg socialnih in delavskih pravic (Burcar 2012) in povečujejo stres, težave na delovnem mestu. Če omenjenemu dodamo še proces individualizacije (stresa) (Pavlič in Šadl 2019), ki spregleda družbenostrukturne razloge za stres, težave zaposlenih, potem je smotrno vprašanje, ali je akademska zaposlitev zaradi tega, ker se nahaja na vrhu piramide javnega šolstva (Burcar 2012), bolj podvržena »vsiljenim diktatom profitno naravnane tržne logike« (str. 223) v primerjavi z zaposlitvijo v vzgojno-izobraževalni (v nadaljevanju VIZ) (osnovnošolski, srednješolski) praksi. Poleg tega menimo, da na doživljanje prehoda vpliva tudi »diktat« vseživljenjskega učenja (Brezovec 2017), ki se na akademski ravni kaže kot samoumevnost, »naravnost« udejanjanja tega koncepta. Izpostavljeno opozarja na skorajda ideološko kontaminiranost, zaradi katere se lahko zgodi, da spregledamo procese, ki kažejo na izrazito podvrženost individualizaciji in osebni izbiri (Rener 2007) in v katerih so kakršna koli stiska, stres in kriza, ki se pojavijo ob prehodu iz strokovne v akademsko sfero, še toliko bolj opredeljeni le kot nesrečne zgodbe posameznikov, ki so rešljive samo individualno, z osebnim delovanjem (Rener 2007), vseživljenjskim učenjem in delom na sebi (Drobnič 2020).

Čeprav je s strani delodajalca tako na praktični kot na akademski ravni sicer pričakovana precejšnja stopnja »aktivacije«, kot jo opredeljujeta Pohl in Walther (2007), pa posameznik postaja vse odgovornejši za lastno (socialno) vključenost, kar pomeni, da se tudi strukturne težave (ki se navezujejo na pogoje in organizacijo, vodenje dela, zaposlenih) individualizirajo in prikazujejo kot zahteve po večji pripravljenosti za sprejemanje tveganih odločitev in po tem, da zaposleni »poskrbijo sami zase« (Ule 2017, 108). S tako obliko individualizacije se zgolj spremeni način družbenega nadzora, ki samostojnost v odločanju nadomešča s t. i. »simulacijo samostojnosti« (str. 109). »Tako se pri- 
tisk k individualizaciji življenjskega poteka sprevrača v svoje nasprotje, v vse večjo odvisnost ljudi od globalnih družbenih institucij, ki jim ponujajo spodporos, še bolj pa jih zavajajo v tržno pogojene in vodene vzorce življenja.« (str. 109) Slednje se potem $v$ akademski praksi odraža tako na makro- kot na mikroravni, ko individualizirani posamezniki pod okriljem iste delovne organizacije nastopajo kot tekmeci v »bitki za statusne simbole in dobiček«. O uspešnosti/neuspešnosti novincev in drugih zaposlenih v tej »akademski bitki«, katere del so tudi identitetni trgi, odloča identitetni kapital (Côté 2000 v Ule 2017), ki ga sestavljajo vsi psihološki in socialni viri posameznika (raznoliki kapitali), s katerimi deluje, se udejstvuje na omenjenih trgih. ${ }^{6}$ Glede na količino identitetnega kapitala, ki je, kot je videti, sestavljen tudi iz kompetenc LifeComp $^{7}$ (Sala idr. 2020) in strategij samoregulacijskega učenja (Zimmerman 1989), je novinec (zaposleni) uspešen/neuspešen v akademski praksi.

Razlika med zaposlitvama poleg številnih drugih odpira tudi že izpostavljeno vprašanje glede soodgovornosti delovnih organizacij za duševno zdravje zaposlenih. Menimo, da tako na ravni prakse kot na akademski ravni ne gre govoriti o kakšni pomembni razliki glede senzibilnosti delodajalcev za počutje in doživljanja svojih zaposlenih, saj so tako eni kot drugi podvrženi preoblikovanju "podjetij» ${ }^{8} v$ smeri zmanjševanja stroškov in zviševanja učinkovitosti. Bistvena razlika je po našem mnenju prav v prisotnosti/odsotnosti kolektivne zavesti in pripadnosti, ki se v praksi še kažeta, kot že rečeno, predvsem zaradi same narave dela in skupnih ciljev, ki jim zaposleni sledijo, v visokošolskem udejstvovanju pa sta opredeljeni bolj kot ovira tekmovalno naravnani neoliberalni akademski karieri.

\section{Problem, namen, cilji raziskave in raziskovalna vprašanja}

$\checkmark$ raziskavi se osredotočimo na podrobnejše razumevanje problematike prehodov med zaposlitvami, ki predstavljajo stalnico individualiziranih življenj-

\footnotetext{
${ }^{6}$ Zavedamo se, da na tak način v razpravo vnašamo neoliberalistično izrazoslovje, s katerim želimo še poudariti problematiko procesov sodobne neoliberalne družbe. Pojme, iz katerih izhajamo, uvede Côté (200o v Ule 2017), ki na podlagi Bourdieujeve teorije kapitalov predlaga pojem identitetnega kapitala, ki poveže pojma človeški in kulturni kapital, nato pa pojasni, da "posameznik na podlagi svojih kapitalskih identitetnih vložkov $v$ prihodnost spobira devidende na identitetnih trgih. Da postane dober igralec na njih, mora najprej vzpostaviti stabilen občutek sebstva, tega pa podpirajo socialne in tehnične spretnosti na številnih področjih dejavnosti, učinkovit vedenjski repertoar in socialni razvoj ter vključenost v ključne socialne in poklicne mreže« (str. 113).

${ }^{7}$ Gre za osebne in socialne kompetence ter kompetence, povezane z učenjem učenja, ki predstavljajo temelj ključnih kompetenc na evropski ravni.

${ }^{8}$ Tu govorimo tudi o šolah, fakultetah kot o podjetjih, o čemer je pisal Laval (2005).
} 
skih potekov (Pavlič in Šadl 2019; Ule 2017). Pri tem največ pozornosti posvetimo prehodu iz zaposlitve strokovnega delavca v vzgojno-izobraževalni praksi v zaposlitev visokošolskega učitelja ( $v$ nadaljevanju prehod), saj menimo, da je slednji specifičen prav zaradi večjih razlik med organizacijo dela, delovnimi mesti ter posledično delovnimi nalogami in načini dela ipd., ki so v primeru zaposlitve na akademski ravni še toliko bolj podvrženi procesom globalizacije in individualizacije. To po eni strani pomeni, da so pričakovanja do novincev (in drugih zaposlenih) podvržena nenehnim zahtevam po samostojnem odločanju in delovanju, ki se mora, pod vplivom »ideologije « ${ }^{9}$ vseživljenjskega učenja (Drobnič 2020), zgolj samomotivirati in samoorganizirati v lastnem učenju (Ule 2017) (kjer je še posebej pomembna samoregulacija) in posledično tudi v profesionalnem udejstvovanju. Po drugi strani pa to pomeni, da so tudi vse težave novincev (pa tudi drugih zaposlenih) še toliko bolj individualizirane, opredeljene znotraj »nesrečnih zgodb posameznikov « (Rener 2007) in posledično je tudi odgovornost za reševanje ter soočanje z njimi zgolj na plečih teh nesrečnih posameznikov.

Kot enega od pomembnih dejavnikov, ravno zaradi individualizacije težav, izpostavimo pojem identitetnega kapitala (Côté 2000 v Ule 2017), ki zajema vse kontekste, pomembne za razvoj (profesionalne, op. a.) identitete $v$ postmoderni družbi, hkrati pa opozorimo na pomen rekonstrukcije težav na delovnem mestu (med katerimi pomembno mesto zavzema stres) (Pavlič in Šadl 2019) iz zgolj individualnega v hkrati družbeno izkustvo, ki s tem postane tudi del strukturne problematike in tako soodgovornost delovne organizacije/delodajalca.

Namen raziskave je raziskati doživljanje in $s$ tem poglobiti razumevanje kompleksnosti prehoda med zaposlitvama pri zaposlenih, ki so ta prehod izkusili, predvsem v povezavi z nekaterimi ključnimi procesi in s pojmi sodobne postmoderne družbe, kot so individualizacija (tudi v povezavi z globalizacijo), identitetni kapital in koncept vseživljenjskega učenja.

$\checkmark$ raziskavi smo sledili naslednjim ciljem:

1. raziskati doživljanje prehoda in vlogo identitetnega kapitala v procesu prehajanja iz ene zaposlitve $v$ drugo pri udeležencih raziskave;

2. ugotoviti prisotnost procesa individualizacije težav (stresa) in posledic le-tega v primerih vključenih udeležencev;

3. preveriti, katere od (organizacijskih, kolektivnih) strategij soočanja s

${ }^{9} \mathrm{Z}$ navednicami želimo opozoriti na nekritično in pretirano idealizirano uporabo koncepta vseživljenjskega učenja, kot jo opisuje Drobnič (2020). 
prehodom bi se udeležencem raziskave zdele koristne in bi po njihovem mnenju olajšale težave, ki so jih imeli sami.

Na podlagi ciljev pa smo izpostavili naslednja raziskovalna vprašanja:

1. Kako bi lahko opredelili prehod, kot ga doživljajo udeleženci raziskave, in kakšno vlogo je imel identitetni kapital v procesu prehajanja?

2. Na kakšen način lahko povežemo načine/strategije soočanja s prehodom s procesom individualizacije težav (stresa) in kakšne posledice za udeležence raziskave bi lahko pripisali temu procesu?

3. Kako udeleženci raziskave ocenjujejo odgovornost delovne organizacije za podporo pri prehodu in kaj menijo o podpori in pomoči v obliki kolektivnih strategij soočanja s težavami (stresom)?

\section{Metodologija}

Izvedli smo kvalitativno raziskavo in uporabili deskriptivno metodo empiričnega pedagoškega raziskovanja. $V$ raziskavo je bilo vključenih osem posameznikov $z$ izkušnjo prehoda iz prakse na akademsko raven zaposlitve $v$ okviru slovenskega vzgojno-izobraževalnega sektorja. ${ }^{10}$ Izkušnja prehoda je bila glavni kriterij za sicer namenski izbor udeležencev raziskave. $V$ preglednici 1 so prikazani za raziskavo relevantni podatki o udeležencih.

Z vsakim od udeležencev smo preko aplikacije ZOOM izvedli polstrukturiran intervju, ki je zajemal deset izhodiščnih vprašanj. Zbiranju podatkov je sledila kvalitativna obdelava le-teh, $v$ kateri smo izpostavljenim kodirnim

${ }^{10}$ Zaradi zagotavljanja anonimnosti smo navedli zgolj najsplošnejši naziv za trenutno zaposlitev tako $v$ praksi kot na akademski ravni.

Preglednica 1 Relevantni podatki o udeležencih raziskave

\begin{tabular}{lllll}
\hline$(1)$ & $(2)$ & $(3)$ & $(4)$ & $(5)$ \\
\hline Oseba A & 64 & 39 & $6-7$ & Visokošolski učitelj \\
Oseba B & 46 & 17 & 4 & Visokošolski učitelj \\
Oseba C & 41 & 18 & 1 & Visokošolski učitelj \\
Oseba D & 39 & 15 & 1 & Visokošolski učitelj \\
Oseba E & 36 & 12 & 2 & Strokovni delavec v vzgojnem zavodu \\
Oseba F & 52 & 25 & 4 & Visokošolski učitelj \\
Oseba G & 47 & 22 & 5 & Strokovni delavec v varstveno-delovnem centru \\
Oseba H & 45 & 18 & 3 & Strokovni delavec v osnovni šoli \\
\hline
\end{tabular}

Opombe (1) udeleženci raziskave, (2) starost, (3) leta delovne dobe, (4) število menjav zaposlitve, (5) trenutno delovno mesto. 
enotam pripisali kode (1. in 2. reda), nato združevali v pojme in nazadnje $v$ nekaj ključnih kategorij. Z vzpostavljanjem razmerja med pojmi in ključnimi kategorijami (s pomočjo določanja nadpomenk $z$ analizo pridobljenim pojmom) smo odgovarjali na izpostavljena raziskovalna vprašanja.

\section{Rezultati in razprava}

V okviru prvega raziskovalnega vprašanja v zvezi z definiranjem prehoda, kot ga doživljajo udeleženci raziskave, in z vlogo identitetnega kapitala v procesu prehajanja smo izpostavili kategorijo Definiranje in doživljanje prehoda s pojmi: razlogi za odločitev za prehod in pričakovanja glede nove zaposlitve, spoznanja glede realnosti/nerealnosti pričakovanj (v zvezi z novo zaposlitvijo), podobnosti/razlike med zaposlitvama, doživljanje in soočanje s spremembami (nove zaposlitve) in uspešnost/neuspešnost adaptacije.

$\checkmark$ okviru drugega vprašanja v zvezi s povezavo med načini/strategijami soočanja s prehodom in procesom individualizacije težav (stresa) ter posledicami procesa za udeležence raziskave smo identificirali kategorijo Načini soočanja s prehodom s pojmi: osamljenost, samoodgovornost za soočanje in (socialna) vključenost $v$ delovno okolje.

Pri tretjem - kako udeleženci raziskave ocenjujejo odgovornost delovne organizacije za podporo pri prehodu in kaj menijo o podpori in pomoči v obliki kolektivnih strategij soočanja s težavami (stresom) - pa smo v analizi izpostavili kategorijo Vloga delovne organizacije pri prehodu in predlogi podpore ter pomoči novincem, ki zajame tudi pojma vloga delovne organizacije in predlogi podpore in pomoči.

$\checkmark$ preglednici 2 predstavljamo pojme in ključne kategorije, ki smo jih v analizi identificirali glede na zastavljena raziskovalna vprašanja.

\section{Definiranje in doživljanje prehoda}

Odločili smo se, da kategoriji definiranje in doživljanje prehoda v rezultatih predstavimo združeno, saj sta $v$ neločljivem razmerju - prepričanja udeležencev o prehodu (s pomočjo katerih udeleženci definirajo prehod) so tesno povezana $z$ doživljanjem le-tega. Obe kategoriji sta $v$ soodvisnosti tudi od osebnega in profesionalnega kapitala (slednja pa sta del identitetnega).

Na podlagi analize odgovorov bi prehod lahko definirali kot proces oz. prehodno obdobje, $v$ katerem posameznik preide iz ene zaposlitve $v$ drugo in $v$ katerem se sooča s spremembami, ki jih obdobje prinaša. V grobem bi lahko ta proces razdelili na tri faze, in sicer: (1) fazo odločanja za prehod oz. sprejemanja odločitve, (2) fazo izpeljave odločitve, povezano $z$ menjavo zaposlitve, in (3) fazo (bolj ali manj uspešne) adaptacije, ki bi jo lahko opredelili tudi kot 
Preglednica 2 Rezultati kvalitativne analize: ključni pojmi in kategorije

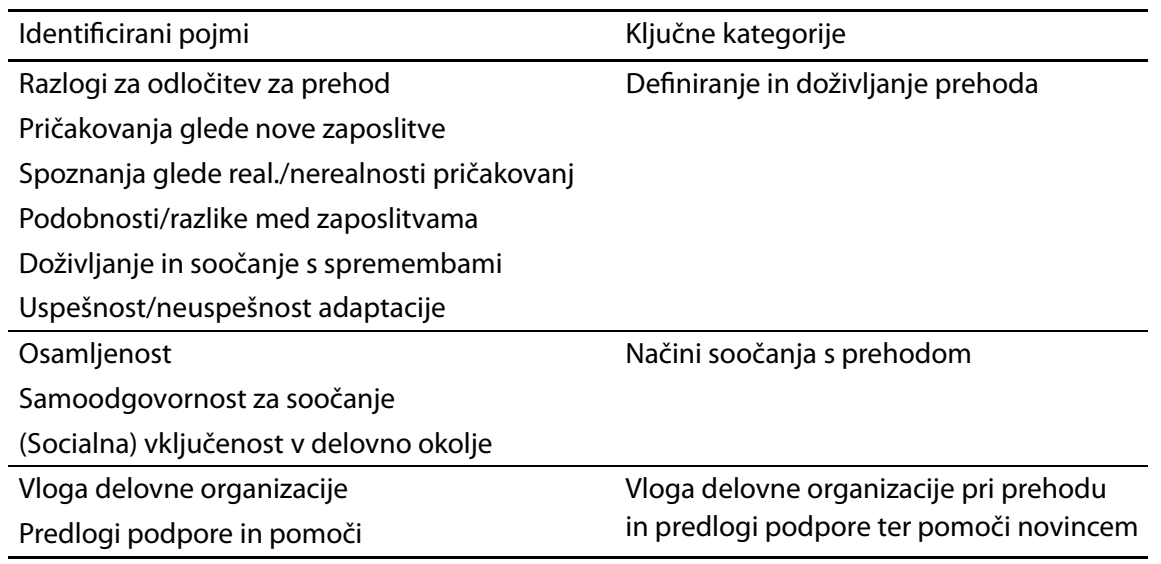

konec prehoda. Faze prehoda lahko povežemo s podkategorijami, in sicer prvo fazo opredelijo predvsem razlogi za odločitev za prehod in pričakovanja glede nove zaposlitve, drugo fazo najbolj definirajo spoznanja glede realnosti/nerealnosti pričakovanj v zvezi z novo zaposlitvijo, podobnosti/razlike med zaposlitvama ter doživljanje in soočanje s spremembami nove zaposlitve in tretjo fazo predvsem uspešnost/neuspešnost adaptacije.

$\checkmark$ prvi fazi se je $v$ povezavi z razlogi za menjavo kot najpomembnejši izkazal osebni kapital v povezavi z razvojno strategijo reševanje (identitetne) krize, kjer gre za to, da »človek z razvojno strategijo zaupa v svoje sposobnosti in moč, $v$ identitetnih odločitvah neobremenjeno upošteva več različnih možnosti« (Ule 2017, 114). Kljub temu, da se je pri nekaterih udeležencih $\left(5^{11}\right)$ že $v$ drugi fazi pokazal dvom vase in obremenjenost $z$ odločitvijo, bi lahko rekli, da je za začetni zagon in razlog za odločitev zagotovo odgovorna prisotnost razvojne naravnanosti. Vendar pa je analiza kot pomembne razloge pokazala nekatere sestavine osebnega kapitala - flegmatičnost (1), radovednost in vedoželjnost (7) (oseba A: »predvsem pa firbec, jaz sem tako firbčen človek, da me vse zanima, če mi kdo kaj ponudi, si rečem, joj, saj bom crknila od dela, ampak grem, tko da $v$ bistvu radovednost [...] al pa želja po novem znanju«), pripravljenost na tveganje (3) pa tudi neinformiranost (6), nevednost (3), nerealna pričakovanja (8) ipd., ki pa jih z izjemo radovednosti (vedoželjnosti) in pripravljenosti na tveganje (fleksibilnosti) ne moremo umestiti med LifeComp (Sala idr. 2020) oz. zaželene razvojne kompetence, ki za odgovorne odločitve predpostavljajo tudi preudarnost, premišljenost

\footnotetext{
${ }^{11}$ Na tak način prikazujemo število udeležencev, pri katerih je odgovor vseboval ta kod.
} 
in informiranost. Po drugi strani med pomembnimi razlogi za prehod razberemo razvojno osebnostno naravnost, ki jo opredeljujejo tendence po profesionalni rasti (2), poglabljanju lastnega znanja (8) in razvijanju idej (pri delu s študenti in znanstvenem raziskovanju) (7) ter nekatere lastnosti in kompetence, med katerimi iz analize razberemo radovednost in vedoželjnost (7), ter prepričanost v pomen vseživljenjskega učenja, ki je pomembna sestavina identitetnega kapitala (Côté 2000 v Ule 2017) in kaže na aktivno vpletenost v lasten profesionalni razvoj.

Med naslednjega od pomembnih razlogov v prid odločitvi za menjavo so pričakovanja v smislu dela na fakulteti kot prestižu (tudi na podlagi družbene percepcije) (7), kot to opredeli oseba E: »Ker vseeno, akademske vode so tko [...] maš eno pozicijo, ki je vseeno malo bolj pomembna«. In oseba C: »tak, da se mi je zdelo pač fensi, ne«, kar izraža dvom v pričakovano prisotnost aktivne oblike individualizacije ${ }^{12}$ (Côté 2000 v Ule 2017) kot pokazatelja prisotnosti dovoljšne količine identitetnega kapitala, saj podrejanje družbenim pričakovanjem ni aktivna oblika vpletenosti v lasten karierni in osebnostni razvoj.

Med razlogi za prehod udeleženci izpostavljajo priložnost $v$ obliki vabila enega od že zaposlenih na fakulteti (ki je bilo posledica priporočila o udeležencu oz. poznavanja udeleženca s strani enega od zaposlenih), ki se je pojavila bolj naključno kot ne. Brez socialnega kapitala se torej zaposlitev verjetno ne bi zgodila.

Naslednji od razlogov so tudi pričakovanja udeležencev glede bodoče zaposlitve, med katerimi vsi udeleženci izpostavijo ideje o prenosu prakse in izkušenj na študente, nekateri pa tudi več svobode (pri sami organizaciji dela in pri vsebinah) (3) ter številne možnosti, ki jih delo na fakulteti odpira (v smislu vplivanja na spremembe, sodelovanja $z$ drugimi institucijami ipd.) (2). Pravzaprav nihče od udeležencev ni načrtoval zaposlitve na fakulteti niti lastne kariere na splošno, kar zopet postavlja pod vprašaj aktivno obliko individualizacije (Côté 2000 v Ule 2017) kot tudi novodobna merila, ki jih navaja Drobnič (2020), po katerih je na trgu dela uspešen le tisti, ki zelo zavestno in zavzeto načrtuje svojo kariero. Menimo, da za vključene v raziskavo ne bi mogli reči, da nimajo uspešne kariere.

$\checkmark$ drugi fazi gre za izpeljavo odločitve, torej za obdobje, ko je posameznik že novinec na fakulteti, torej v vlogi visokošolskega učitelja. V samih za-

\footnotetext{
${ }^{12}$ Gre za obliko individualizacije, v kateri posamezniki ne sledijo zgolj trendom in stilom, ki jih narekuje sodobna potrošniška družba, ampak so aktivno vpleteni v »potek svoje osebnostne rasti in poklicne kariere« (Côté 2000 v Ule 2017, 114).
} 
četkih počasi prihajajo do spoznanj glede realnosti/nerealnosti pričakovanj, pri čemer se izkaže, da na samem začetku prav vsi idealizirajo akademsko prakso in se na podlagi izkušenj potem soočajo z razočaranostjo (oseba C: »To sem pričakovala, realnost je bla pa pač drugačna«, oseba B: »To so bila moja pričakovanja, potem sem pa hitro padla na realna tla«). Na podlagi tega izpostavijo nekatere podobnosti - $v$ povezavi s profesionalnimi/osebnostnimi lastnostmi -, predvsem pa razlike med zaposlitvama, povezane $z$ individualizacijo (8) (Oseba E: »Ta individualizem sem res doživela«), »naravo« in vrednotenjem dela (7), vlogo in pomenom delovne organizacije (5) in formalno vključenostjo vanjo (1). Pri doživljanju in soočanju s spremembami nove zaposlitve pa bi za večino udeležencev ( $z$ izjemo enega ${ }^{13}$ ) lahko rekli, da iz začethe vznesenosti in vznemirjenosti, tudi zaradi nerealnih pričakovanj, vstopijo $v$ proces žalovanja za prejšnjo zaposlitvijo, ko se soočajo z občutki osamljenosti (7), nekompetentnosti (5), nesprejetosti (7), manjvrednosti (5), strahu (5), obžalovanja menjave (5), ki se v fazi adaptacije, skorajda premo sorazmerno s stopnjo socialne vključenosti, seveda zmanjšajo oz. jih ne čutijo več tako pogosto. Lahko bi torej rekli, da gre pri večini udeležencev (7) tudi vsaj za manjšo identitetno krizo, povezano s t. i. udejstvovanjem na novem (profesionalnem) identitetnem trgu (Côté 2007 v Ule 2017), kar oseba D opiše: »Kot da sem neko profesionalno identitetno krizo doživela, ker kar naenkrat nisem bila več vredna skorajda nič kot strokovnjakinja, ampak sem se morala učiti, kako postati znanstvenica."

$V$ fazi adaptacije se uspešnost/neuspešnost le-te najbolj neposredno kaže prav z vztrajanjem na istem delovnem mestu (uspešna adaptacija) pri petih udeležencih oz. $z$ menjavo delovnega mesta, prehodom $z$ akademske ravni nazaj v prakso (neuspešna adaptacija) pri treh udeležencih raziskave. Odločitve, povezane $z$ vztrajanjem/menjavo zaposlitve, so glede na doživljanje udeležencev močno povezane $z$ bolj ali manj uspešno vključitvijo $v$ novo delovno okolje, z uspešnim izvajanjem vseh delovnih nalog, ki jih prinaša novo delovno mesto, in usvajanjem sistema pisanih/nepisanih pravil nove delovne organizacije oz. s pretežno celostnim sprejemanjem nove zaposlitve.

Analiza je pokazala, da udeleženci največji pomen v procesu adaptacije pripisujejo socialni vključenosti (torej socialnemu kapitalu), saj prav vsi izpostavljajo pomen dobrih socialnih stikov, občutek sprejetosti med podobno

\footnotetext{
${ }^{13}$ Gre za primer udeleženca, ki je na svoji poklicni poti doživel največ prehodov med zaposlitvami in je tudi najstarejši izmed udeležencev ter z najdaljšo delovno dobo. Sprašujemo se, če izkušenost prehajanja med zaposlitvami, še bolj pa sama starost vpliva na doživljanje prehoda, predvsem z vidika zasičenosti s prakso in utrujenosti od prakse v obliki nenehnega dela z otroki/mladostniki?
} 
mislečimi kolegi in nekateri tudi formalno vključenost $v$ delovanje fakultete (3), kar oseba B opiše takole: „Zdaj imam filing, da bi lahko poklicala kogarkoli pa z njim sodelovala, no, ne glih kogarkoli, ampak veliko večino mojih sodelavcev, ker čutim pripadnost organizaciji zdaj in se čutim del tega, zdaj sem tu že tri leta [...] in zadaj čutim pripadnost. [...] S tistimi, ki sodelujem, smo se začutili [...], vidiš, kdo je na isti valovni, vidiš, kje si dobrodošel in kje so ti vrata na strežaj odprta.« Kot ovire takemu vključevanju pa vidijo zelo slabe odnose na ravni fakultet, na katerih so zaposleni, in posameznih oddelkov (4), nekolegialnost in nemotiviranost kolegov za izboljšanje odnosov (2), pomanjkanje pripadnosti (5), individualizem (4) in tekmovalnost (3). Tisti, ki so se uspešno vključili (4), navajajo tudi pomembnost vloge kolegov, ki so samoiniciativno prevzeli vlogo nekakšnih mentorjev $v$ tem procesu adaptacije in jim olajšali tudi spoznavanje delovnih nalog, usvajanje sistema delovne organizacije. Če kategorijo socialne vključenosti povežemo še z razlikami med zaposlitvama, je potrebno izpostaviti, da večina med slednje umesti tudi hitrost adaptacije, kar pomeni, da so se na delovnih mestih strokovnih delavcev v VIZ praksi vedno hitreje in bolje adaptirali, doživljali večji občutek pripadnosti, več kolegialnosti, medtem ko na ravni akademske zaposlitve ta proces poteka počasneje, kot razlog za to pa navajajo naravo dela.

Če v zaključku izpostavljeno kategorijo, Definiranje in doživljanje prehoda v vseh treh fazah, povežemo z identitetnim kapitalom, ugotovimo, da analiza odgovorov pri udeležencih raziskave pokaže na prisotnost večine sestavin le-tega, ki jih našteje Côté (2000 v Ule 2017) - stabilen občutek sebstva (ki je osnova za razreševanje identitetnih kriz in o katerem lahko sklepamo iz odgovorov glede načinov soočanja, ki jih bomo natančneje predstavili v nadaljevanju), socialne (in tehnične) spretnosti, nabor učinkovitih vedenjskih odzivov, nenehen osebni in profesionalni razvoj (vseživljenjsko učenje, op. a.), vključenost v raznolike socialne mreže, lastna motivacija, divergentno mišljenje, kritična zavest, psihološka moč, samozaupanje, samoregulacija itn., torej osebni, socialni, izobrazbeni, kulturni, ekonomski itn. kapital. Poleg količine sestavin, ki jih vsebuje posameznikov identitetni kapital, pa bi lahko vsaj deloma potrdili, da je za uspeh na novem delovnem mestu pomembno tudi, da gre pri njem za t. i. aktivno obliko individualizacije (ki bi jo lahko povezali tudi s pojmom »aktivacije« (Pohl in Walther 2007)) in razvojno strategijo spopadanja z identitetnimi krizami, ki so posledica nenehnega udejstvovanja na identitetnih trgih (Côté 2000 v Ule 2017). Prehod med zaposlitvama lahko že sam po sebi, kot je ugotoviti tudi iz analize, predstavlja izvor identitetne krize, saj posameznik z novo zaposlitvijo vstopa na nov (profesionalni) identitetni trg, podvržen visoki stopnji individualizacije. 


\section{Načini soočanja s prehodom}

Kategorijo Načini soočanja s prehodom natančneje definirajo osamljenost, samoodgovornost za soočanje in (socialna) vključenost $v$ delovno okolje.

Začetki osamljenosti in samoodgovornosti za reševanje se pojavijo že $v$ prvi fazi in potem $v$ sami izpeljavi prehoda $v$ obliki notranjega konflikta pri posameznikih, ki ga je občutilo sedem udeležencev. Najmočnejši notranji konflikt imajo tisti (5), ki so se na prejšnjem delovnem mestu zelo dobro počutili (zaradi odnosov $v$ timu sodelavcev, odnosov $z$ učenci) in/ali pa so $z$ veseljem opravljali svoje delo (pretežno z otroki/mladostniki) (2), kot oseba C: »In ta odločitev je bila strašno težka, ker meni res, meni je bilo v šoli fajn, meni so bli otroci fajn, meni je bla slovenščina fajn, vse mi je bilo fajn in potem sem v bistvu rabla kar neki časa, no [.. .].« Kot smo že rekli, analiza kaže, da pri vseh udeležencih na koncu prevladajo radovednost, vedoželjnost in občutek časti ter ponosa, da bodo zaposleni na fakulteti (prestiž).

Vsi udeležencih raziskave, predvsem $v$ drugi fazi procesa prehoda, izpostavijo/opišejo občutek osamljenosti, ki jo še povečujejo prepričanja o samoodgovornosti za reševanje lastnih težav, ki jih lahko razberemo iz samoumevnosti odgovorov, $v$ smeri, da je to zasebna stvar, kljub temu da težave izvirajo tudi iz novega delovnega okolja. Udeleženci se z lastnimi dilemami in notranjimi konflikti soočajo predvsem sami (8) in nekoliko tudi v krogu najintimnejših odnosov (z družinskimi člani, partnerji, najbližjimi prijatelji) (6). Počutijo se čisto sami in edini v taki stiski (6) in pet jih izpostavi, da se njihova občutja takrat ne skladajo z družbenimi pričakovanji, ki so jih izražali tudi njihovi najbližji, kot o tem poroča oseba H: »Najtežje mi je bilo, ker sem se v tem počutil zelo osamljeno in si tega niti nisem upal deliti s komerkoli, saj me je bilo na nek način sram, ker imam pa ja idealno službo, za katero moram biti hvaležen.« To slednje in občutek, da se neprijetne emocije pojavljajo samo pri njih samih, jih ovira pri tem, da bi se o lastnem doživljanju pogovarjali s kom od novih kolegov. Večini (7) se zdi tudi, da pogovor o občutkih v zvezi z novo zaposlitvijo ne sodi v delovno okolje, ni del organizacijske kulture.

Pomembna ovira v odnosih z izkušenejšimi, bolje izobraženimi kolegi je poleg nepoznavanja novih kolegov (8) tudi občutek manjvrednosti, nekompetentnosti, ki ga je občutilo kar pet udeležencev in je lahko posledica pomembnosti hierarhije in nazivov, ki jo izpostavi kar šest udeležencev, kot npr. oseba B: "Se ne morem znebiti občutka vseeno, da se zelo, zelo veliko težo daje titulam." Tudi odgovor udeleženca, ki izpostavi, da je formalna vključenost $v$ organe in komisije na fakulteti prispevala $k$ zmanjšanju občutkov osamljenosti in povečanju občutkov pripadnosti, lahko priča 
o pomenu formalnih vlog ( $v$ povezavi z nazivi) na ravni akademske zaposlitve.

Če izpostavimo načine in strategije, ki so pripomogli k adaptaciji, je očitno, da so ti skorajda izključno odvisni od posameznika in delovanja na identitetnih trgih (Côté 2000 v Ule 2017), med katerimi bi izpostavili predvsem (a) osebnega, $v$ katerega štejemo osebnostno naravnost, lastnosti in kompetence ter samoregulacijske strategije, ki omogočajo reševanje (identitetnih) kriz z razvojno strategijo (Ule 2017) - pogum za soočanje z izzivi, odprtost do sprememb, pripravljenost na učenje, sposobnost iskanja virov podpore in pomoči v primerih intenzivnih neprijetnih čustev (pa čeprav zunaj delovne organizacije), čustvena inteligentnost in metakognitivne sposobnosti (v primerih opredeljevanja in analize lastnega procesa soočanja s prehodom ter osmišljanja in ocene lastne delovne uspešnosti), ter (b) zasebno-socialnega, $s$ katerim imamo $v$ mislih predvsem vse (intimne) podporne odnose udeležencev, ki so slednjim na voljo.

Slednje, torej socialni kapital, pa lahko povežemo s kategorijo (socialne) vključenosti v delovno okolje, ki je v primeru vključevanja na akademsko raven glede na ugotovitve analize predvsem odgovornost novincev. Večina (7) je sicer imela vsaj en znan socialni stik - z osebo, ki je udeleženca povabila na fakulteto (kot kaže, vodje fakultet polno odgovornost za vpeljavo novincev prelagajo na tega posameznika), vendar pa razen tega delovna organizacija, po pripovedovanju udeležencev, ne kaže nobenega zanimanja oz. podpore novincem. V povezavi z izkušnjami iz prakse posamezniki izpostavijo, da jih za razliko od vzgojno-izobraževalne institucije, v kateri so delali, nihče ni predstavil širšemu kolektivu (8), nihče ni pojasnil, kako delujejo strokovne službe in kdo so pomembnejši strokovni sodelavci (5) ipd., kar kaže izjava osebe C: »Pač, ona je bila tista, ki je bila takrat meni nadrejena, jaz pojma nisem imela o tem, kak je ustroj na fakulteti, ne, jaz nisem vedla, da je to ena taka institucija z milijardo službami, ne, in imela sem en kup vprašanj, na katera ona ni imela odgovora in se tudi ni potrudila, da bi te odgovore dobila. Jaz pa na fakulteti nisem poznala nikogar, na kogar bi se lahko obrnila.« Vsi udeleženci se tako povezujejo predvsem z bližnjimi sodelavci iz oddelka in nekateri (5) sčasoma tudi s tistimi, ki jih naključno srečajo in začutijo npr. v sejni sobi. Pomemben preobrat $v$ soočanju s prehodom, predvsem $v$ primeru prisotnosti neprijetnih emocij, se pri večini udeležencev (6) zgodi s povečanjem socialnega kapitala na delovnem mestu, $v$ povezavi z občutkom sprejetosti, pripadnosti (pa tudi smiselnosti in uspešnosti na individualni ravni), ki ga eden od udeležencev pripiše tudi formalni vključenosti v delovno organizacijo, kar kaže na velik pomen socialne vključenosti ter kolegialne pomoči in podpore. 
Socialna vključenost je na organizacijski ravni popolnoma spregledana, kar pripisujemo procesu individualizacije težav (stresa) (Pavlič in Šadl 2019), in prepuščena zgolj samoiniciativnosti zaposlenih ter solidarnosti do kolegov novincev.

Odgovori tega sklopa potrdijo zgodbo o nesrečnem posamezniku (Rener 2007), ki se mora aktivirati (Pohl in Walther 2007) in znati poskrbeti zase (Ule 2017), sicer je v prehodu oz. v profesionalni karieri opredeljen kot neuspešen. Kriteriji za uspešnost/neuspešnost glede na teoretska izhodišča ostajajo podobni ne glede na specifiko prehoda, pa vendar je, kot kažejo tudi ugotovitve analize, na ravni pedagoške vzgojno-izobraževalne prakse, že zaradi same narave dela $z$ vsakodnevno fizično navzočnostjo na delovnem mestu, v skupnih prostorih s sodelavci, z delegiranimi delovnimi nalogami, ki so velikokrat timske in stremijo $\mathrm{k}$ skupnim ciljem na dnevni bazi, vseeno pričakovati nekoliko več kolektivne zavesti in pripadnosti (Oseba G: »In ta občutek pripadnosti je bil močan, močan«), kar posledično lahko pomeni tudi več medsebojne podpore in pomoči med zaposlenimi v primeru težav (Oseba G: »Se bo hitro nekdo našel pa ti kaj pokazal [...]«). To je v nasprotju $z$ akademsko/znanstveno ravnjo zaposlitve, ki s hierarhično organiziranostjo in zelo natančnim razmejevanjem področij dela ter tudi zaradi korporativnomenedžerskih meril kakovosti akademskega dela, o katerih govori Burcarjeva (2012), pričakuje predvsem samostojnega in hkrati pokorljivega ${ }^{14}$ posameznika, nosilca lastnega interesnega področja oz. področja raziskovanja, ki naj le replicira že znan, demagoško preverljiv, sprejemljiv in objavljen akademski diskurz, kar oseba D opiše: »Sem zelo timski človek [...], ampak v akademskih vodah je to [...] tudi če si individualist, boš prišel daleč, [...] ja, moraš non stop neki dohajat, ampak sem mela občutek, da je samo sebi namen, predvsem zato, da so neke točke, da dobiš akreditacijo [habilitacijo, op. a.], torej da tle, čim več objav, čim več ... mislim, sem zgubila, meni ne bi blo težko to delat, če bi vidla smisel, če bi vedla, da se bo zaradi tega nekaj spremenilo v praksi al pa neki bo izboljšanje [...].« Poleg tega pa s pomočjo kompetenc za vseživljenjsko učenje - kompetence LifeComp (Sala idr. 2020) - in samoregulacijskih strategij učenja (Zimmerman 1989) prevzame popolno odgovornost za motivacijo in organizacijo lastnega učenja ${ }^{15}$ in s tem posledično za lasten življenjski potek (Ule 2017), iz česar je sklepati tudi o individualizirani odgovornosti za izvedbo, organizacijo lastnega dela in profesionalnega razvoja.

\footnotetext{
${ }^{14}$ Ne pa tudi avtonomnega, saj Burcarjeva $(2012,258)$ opozarja, da neoliberalni diskurz znanstvenikom odvzema njihovo avtonomijo in jim odreka zmožnost lastnega ekspertnega presojanja.

${ }^{15}$ Vedno bolj pa tudi učenja študentov.
} 


\section{Vloga delovne organizacije pri prehodu in predlogi podpore in pomoči novincem}

Vloga delovne organizacije pri prehodu je glede na ugotovitve analize pravzaprav nična, saj temelji le na predhodnih poznanstvih in/ali pa samoiniciativnosti novinca, zato vsi udeleženci raziskave predlagajo načrtno podporo in pomoč novincem. Izpostavijo tako individualno pomoč v obliki tutorstva (2), mentoriranja (2) oz. podpore in pomoči vodje oddelka (3), ki ni nezdružljiva z obema predhodnima, in kolektivnejšo, skupinsko pomoč $v$ obliki podpornih skupin (2), skupin za samopomoč (1), posebnih delovnih skupin (6), ki bi bile sestavljene predvsem iz zaposlenih, ki so se pred kratkim uspešno adaptirali, ali pa takih, ki so prav tako šele prišli, ter supervizij, intervizij (1). Nihče od udeležencev tovrstne inscenirane kolektivne podpore in pomoči ne predlaga samoiniciativno, ampak šele nanašajoč se na vprašanje v intervjuju o potrebi take pomoči in podpore. To samo potrjuje prisotnost sprejemanja individualizacije težav (stresa) na delovnem mestu (Pavlič in Šadl 2019) kot objektivne realnosti.

Kljub vsemu pa $v$ tem, da so se vsi udeleženci raziskave ( $\mathrm{z}$ izjemo enega) večinoma soočali s podobnimi emocijami $v$ procesu prehoda in so posledično izražali potrebo po podpori ter pomoči za novince znotraj delovne organizacije, lahko vidimo potencial za kolektivno akcijo. $V$ primeru emocionalnega doživljanja novincev govorimo o prisotnosti skupinskih emocij. Zato menimo, da bi delovne organizacije, ki bi priznavale pomembnost skupinskih emocij v stresnih situacijah (kot je tudi prehod), omogočale usklajevanje kolektivnih prizadevanj za doseganje skupnih ciljev, reševanje morebitnih težav, določanje zaželenosti ravnanj glede na prevladujoče skupinske emocionalne norme, opredeljevanje in izpogajanje vlog ter odgovornosti zaposlenih (Barsade in Gibson 1998; van Kleef in Fisher 2015 v Pavlič in Šadl, 2019). Tako bi bil »stres rekonstruiran kot družbeno izkustvo [...], ki nosi političen potencial za spremembe delovnih razmer (Pavlič in Šadl 2019, 39). Poleg rekonstruiranja stresa pa bi bilo pomembno, da bi delovne organizacije »legitimirale emocionalnost znotraj delovnega konteksta z vzpostavljanjem organizacijske kulture, ki bi eksplicitno spodbujala svobodno izražanje emocij med zaposlenimi« (str. 39).

\section{Sklepne ugotovitve}

Na podlagi odgovorov udeležencev raziskave lahko ugotovimo prežetost njihovega doživljanja s postmodernimi družbenimi procesi. Nakazuje se problematika individualizacije težav v primeru prehajanja med zaposlitvami, samoumevnosti vseživljenjskega učenja, kjer pomembno vlogo, tudi zaradi od- 
sotnosti kolektivne podpore, igra količina identitetnega kapitala posameznikov. Omenjene vsebine se natančneje odražajo v odgovorih udeležencev, povezanih s ključnimi raziskovalnimi vprašanji.

Definiranje prehoda, ki ga je razbrati iz analize pogovorov, kaže na proces prilagajanja na spremembe, ki je tako že v izhodišču odvisen od pomembnih sestavin identitetnega kapitala (Côté 2000 v Ule 2017). Tudi sam potek procesa prehoda je $v$ veliki meri povezan $z$ identitetnim kapitalom in $\mathrm{s}$ t. i. sposobnostjo delovanja na identitetnih trgih, kot je to ugotovil že Côté (2000 v Ule 2017). Med slednjimi bi izpostavili profesionalni, socialni, izobraževalni in ekonomski trg. Udeleženci raziskave poleg osebnega kapitala, ki ga sestavljajo tudi osebnostne lastnosti in profesionalne kompetence ter načini soočanja s spremembami, ki so individualizirani, in izobraževalnega kapitala, kjer je udejanjanje vseživljenjskega učenja nujno, izpostavijo socialni kapital kot ključen za uspešno adaptacijo in prehod.

$\checkmark$ vsem tem ne moremo spregledati vplivov procesov globalizacije (kot o tem Uletova (2017)), ki se pri udeležencih kažejo tako, da ne problematizirajo pretiranega ukvarjanja s samimi seboj (kot o tem Pavličeva in Šadlova (2019)) in spregledajo vse socio-kulturne ter ekonomske dejavnike, ki jim omogočajo čas in prostor za to. Poleg tega pa dolgotrajnost procesa adaptacije na akademsko raven lahko priča tudi o tem, da vsi že zaposleni akademiki pred solidarnost, kolektivno podporo in pomoč novincem postavijo čas zase oz. čas za izpolnjevanje delovnih nalog v primežu diktata učinkovitosti in produktivnosti (kot o tem Burcarjeva (2012)).

$Z$ analizo ugotovljeni načini in strategije soočanja s prehodom kažejo na sprejemanje izključne samoodgovornosti za reševanje težav, ki je posledica individualizacije kot naravne, objektivne stvarnosti. Slednje kaže na to, da so udeleženci raziskave ponotranjili družbena pričakovanja, v katerih je tudi prisila, da nekatere sicer družbene zahteve, odgovornosti, urejanja posamezniki prevzamejo nase (kot o tem Uletova (2017)). Od tod izvira pogost občutek osamljenosti, na nek način pa tudi neadekvatnosti doživljanja, saj se to ne dogaja nikomur drugemu razen njim samim, zato so dolžni poskrbeti zase. Tisti, ki ne posedujejo dovolj identitetnega kapitala, predvsem v obliki osebnostnih lastnosti in kompetenc (osebni kapital), ki omogočajo razvojno strategijo soočanja s krizami (Côté 2000 v Ule 2017), in nimajo zasebnega socialnega kapitala - podpornih odnosov z bližnjimi, se verjetno za prehod niti ne odločajo.

Pri zadnjem vprašanju se udeleženci raziskave sicer strinjajo, da je delovna organizacija vsaj deloma soodgovorna za podporo novincem (in drugim zaposlenim) pri prehodu (in tudi v primeru drugih težav), hkrati pa večinoma 
izpostavljajo, da organizacija ne legitimira emocionalnosti na delovnem mestu in ne zaznava težav posameznikov. Vsi se strinjajo, da bi morala ponujati razne oblike kolektivnih strategij soočanja s stresom. Slednje poudarjata tudi Zakon o varnosti in zdravju pri delu (v nadaljevanju ZVZD-1) (2011) in "Smernice za promocijo zdravja na delovnem mestu« (v nadaljevanju »Smernice«) (Ministrstvo za zdravje 2015), in sicer da bi delodajalci morali nameniti večji poudarek psihosocialni dobrobiti zaposlenih in ne samo zdravju kot odsotnosti fiziološke bolezni; tako bi lahko izvajali ukrepe na primarni, sekundarni in terciarni ravni (Pavlič in Šadl 2019). Vendar pa, podobno kot Pavličeva in Šadlova (2019), v raziskavi tudi sami ugotavljamo, da ne prihaja do implementacije z ZVZD-1 (2011) in s "Smernicami« (Ministrstvo za zdravje 2015) predvidenih dejavnosti.

Kljub vsem znanstvenim uvidom in razpravam tudi na ravni akademskih zaposlitev potrebujejo t. i. inscenirane skupnosti, o katerih je govoril že Beck (2001), in sicer v obliki delovnih skupin, ki bi poskrbele za novince. Kljub temu, da naj bi na tak način, kot pravita Pavličeva in Šadlova (2019), spodbudili tudi politični potencial za doseganje strukturnih sprememb delovnih razmer, pa ravno ta potreba, ki so jo izrazili tudi vsi udeleženci naše raziskave, kaže na to, da je samostojnost v odločanju nadomestila simulacija samostojnosti (Ule 2017), ko naj bi posamezniki v težavah prejeli pomoč delovne organizacije (kar kaže na odvisnost od družbenih institucij), ker te pomoči (v zadostni meri) ne dobijo od svojih sodelavcev iz čisto človekoljubnih vzgibov in solidarnosti. Slednje pa že odpira nova vprašanja o tem, kam so šli/kam gredo, vsi tisti, ki kaj takega poskušajo, pa jih sodobni kapitalizem, identitetnemu kapitalu navkljub, utrudi, »izpljune« in »izloči iz igre«. V oslabljene sindikate ${ }^{16}$ (Burcar 2012) zagotovo ne.

\section{Literatura}

Barsade, S. G., in D. E. Gibson. 1998. »Group Emotion: A View from Top and Bottom." Research on Managing Groups and Teams 1 (4): 81-102.

Beck, U. 2001. Družba tveganja: na poti v neko drugo moderno. Ljubljana: Krtina.

Brezovec, L. 2017. »Mladi v ujetništvu vseživljenjskega učenja.«Andragoška spoznanja 23 (3): 105-120.

Burcar, L. 2012. »Privatizacija in korporativizacija javne univerze.« Šolsko polje 23 (3-4): 223-290.

\footnotetext{
${ }^{16} \mathrm{~S}$ pojmom želimo izpostaviti vprašanje vloge sindikatov, ki jo sami vidimo tudi v udejanjanju političnega potenciala za doseganje strukturnih sprememb delovnih razmer. Vendar pa, kot piše L. Burcar $(2012,224)$, »jih je postfordistična oblika produkcije in delitve dela prav z outsourcingom in podizvajalstvom številčno oslabila in pogajalsko povsem nevtralizirala«.
} 
Côté, J. 2000. Arrested Adulthood: The Challenging Nature of Maturity and Identity. New York: New York University Press.

Drobnič, J. 2020. »Poklicne odločitve in vodenje kariere v kontekstu avtonomnosti samoodločanja.« Šolsko polje 31 (3-4): 167-184.

Laval, C. 2005. Šola ni podjetje: neoliberalni napad na javno šolstvo. Ljubljana: Ministrstvo za kulturo Republike Slovenije in Javna agencija za raziskovalno dejavnost Republike Slovenije.

Lazarus, R. S. 1976. Patterns of Adjustments. New York: McGraw-Hill.

Lustig, J. 2005. »The University Revisioned: An Alternative to Corporate MisEducation." The Review of Education, Pedagogy, and Cultural Studies 27:1752.

Ministrstvo za zdravje. 2015. »Smernice za promocijo zdravja na delovnem mestu.« https://www.gov.si/assets/ministrstva/MZ/DOKUMENTI/Preventiva -in-skrb-za-zdravje/Promocija-zdravja-na-delovnem-mestu/Smernice _promocija_zdravja_na_delovnem_mestu-marec_2015.pdf.

Pavlič, J., in Z. Šadl. 2019. "Upravljanje stresnih emocij na delovnem mestu.« Družboslovne razprave 35 (91): 29-45.

Pohl, A., in A. Walther. 2007. "Activating the Disadvantaget: Variations in Addressing Youth Transitions across Europe.« International Journal of Lifelong Education 26 (5): 533-553.

Rener, T. 2007. »Globalizacija, individualizacija in socialna izključenost mladih.« IB revija 2 (41): 40-49.

Sala, A., P. Yves, V. Garkov in M. Cabrera. 2020. LifeComp: The European Framework for Personal, Social and Learning to Learn Key Competence. Luksemburg: Publications Office of the European Union.

Ule, M. 2017. „Vloga identitetnih kapitalov v razvoju aktivne odraslosti v globaliziranih družbah."Andragoška spoznanja 23 (4): 103-120.

van Kleef, G. A., in A. H. Fisher. 2015. »Emotional Collectives: How Groups Shape Emotions and Emotions Shape Groups."Cognition and Emotion 30 (1):3-19.

Zakon o varnosti in zdravju pri delu (ZVZD-1). 2011. Uradni list Republike Slovenije, št. 43. https://www.uradni-list.si/1/objava.jsp?sop=2011-01-2039.

Zaviršek, D. 2018. Skrb kot nasilje. Ljubljana: *cf.

Zimmerman, B. J. 1989. »Models of Self-Regulated Learning and Academic Achievement." Journal of Educational Psychology 81 (3): 329-339.

\section{Experiencing the Transition from Pedagogical Practice at the Primary and Secondary Level to a Teaching Position at the Academic Level of Education in the Context of Postmodern Society Processes}

We included eight individuals in the qualitative research of the experience of the above-mentioned transition in connection with certain processes of contemporary postmodern society. The analysis has shown the presence of consequences of individualisation (individualisation of problems, the dictatorship 
of lifelong learning) which the included individuals accept as a 'natural', selfevident part of transitions. It has pointed out the meaning of having enough identity capital to adapt successfully and confirmed the absence of collective support for the newly employed in the academic sphere.

Keywords: transition between employments, individualisation, identity capital, a teaching position at the academic level of education, postmodern society 